\title{
FENEMONA PEMBAYARAN PAJAK BUMI DAN BANGUNAN (PBB) DI KECAMATAN BANDONGAN KABUPATEN MAGELANG
}

\author{
Heni Farikhatu Sholikhah \\ Magister Ilmu Pemerintahan Sekolah Tinggi Pembangunan Masyarakat Desa “APMD” \\ J1. Timoho No. 317 Yogyakarta (0274) 561971 Email Korespondensi: putriheni111@gmail.com
}

\begin{abstract}
Abstrak: Di negara Indonesia pajak mempunyai peranan yang sangat vital dimana pajak sebagai pendapatan terbesar negara. Besar kecilnya pajak yang diterima oleh negara akan sangat menentukan laju perkembangan roda pemerintahan khususnya dalam melaksanakan pembangunan. Ada beberapa macam pajak yang diterima oleh kas negara salah satunya adalah pajak bumi dan bangunan (PBB). Pajak bumi dan bangunan merupakan iuran wajib kepada kas negara atas dasar kepemilikan, penguasaan dan perolehan manfaat dari bumi dan bangunan besarnya pajak terutang ditentukan oleh keadaan objek yakni bumi/ tanah dan bangunan. Tulisan ini bertujuan menyajikan fenomena kemacetan pembayaran PBB di Kecamatan Bandongan, Kabupaten Magelang dengan menggunakan metode analisis kebijakan. Metode analisis kebijakan adalah suatu disiplin ilmu sosial terapan yang menggunakan argumentasi rasional dengan menggunakan fakta-fakta untuk menjelaskan, menilai, dan membuahkan pemikiran dalam rangka upaya memecahkan masalah publik. Data dihimpun melalui 1) wawancara; 2) observasi; dan 3) dokumentasi. Hasil penelitian ini adalah 1) rendahnya tingkat kesadaran; dan 2) kemiskinan. Rendahnya tingkat kesadaran terlihat dari tunggakan pembayaran PBB oleh wajib pajak (WP), sedangkan kemiskinan dikarenakan rata-rata penduduk Kecamatan Bandongan bekerja sebagai petani atau buruh harian lepas sehingga pendapatan terbatas hanya sebagai pemenuh kebutuhan harian.
\end{abstract}

Kata kunci: Fenomena; PBB; Kecamatan Bandongan.

Abstract: In Indonesia, taxes have a very vital role in which taxes are the largest state income. The size of the tax received by the state will greatly determine the rate of development of the wheels of government, especially in implementing development. There are several types of taxes received by the state treasury, one of which is land and building $\operatorname{tax}(P B B)$. Land and building tax is an obligatory contribution to the state treasury on the basis of ownership, control and benefits of land and buildings. The amount of tax payable is determined by the condition of the object, namely land / land and buildings. This paper aims to present the phenomenon of bottleneck in PBB payments in Bandongan District, Magelang Regency by using the policy analysis method. The policy analysis method is an applied social science discipline that uses rational argumentation by using facts to explain, assess, and generate thoughts in an effort to solve public problems. The data were collected through 1) interviews; 2) observation; and 3) documentation. The results of this study are 1) low level of awareness, and 2) poverty. The low level of awareness can be seen from the unpaid PBB payments by taxpayers (WP), while poverty is due to the fact that the average population of Bandongan District works as farmers or casual daily laborers so that their income is limited only to fulfill their daily needs.

Keywords: Phenomena; PBB; Bandongan District.

Article History :

Received 23 Januari 2021; Revised 01 Februari 2021; Accepted 25 Maret 2021

\section{PENDAHULUAN}

Pajak Bumi dan Bangunan (PBB) adalah pajak yang dipungut atas tanah dan bangunan karena adanya keuntungan dan/atau kedudukan sosial ekonomi yang lebih baik bagi orang atau badan yang mempunyai suatu hak atasnya atau memperoleh manfaat dari padanya. Menurut S.Aji Suryo (2006:14-2) pajak bumi dan bangunan adalah pajak yang dikenakan atau dibebankan atas bumi dan bangunan, pendapat tersebut ditambahkan oleh Erly Suandy (2005:61) pajak bumi dan bangunan adalah pajak yang sifatnya kebendaan dan besarnya pajak terutang ditentukan oleh keadaan obyek yakni bumi/ tanah dan bangunan. Tanggung jawab atas kewajiban pembayaran pajak, sebagai 
pencerminan kewajiban kenegaran di bidang perpajakan berada pada anggota masyarakat sendiri untuk memenuhi kewajiban tersebut. Hal tersebut sesuai dengan sistem self assessment yang dianut dalam Sistem Perpajakan Indonesia.

Masyarakat yang memenuhi kewajiban membayar pajak disebut Wajib Pajak (WP). Wajib Pajak PBB adalah mereka yang secara nyata memiliki hak, memperoleh manfaat, menguasai, dan memperoleh manfaat atas tanah dan bangunan. Sebaliknya, tanah dan bangunan yang digunakan untuk kepentingan umum, seperti untuk sarana pendidikan, ibadah, kesehatan, lahan pemakaman, dan sejenisnya maka tidak termasuk objek pajak PBB.Kriteria objek PBB telah tercantum dalam UndangUndang Nomor 12 Tahun 1994 tentang Pajak Bumi dan Bangunan. Karena telah tercantum dalam Undang-Undang, maka membayar pajak PBB bersifat wajib dan apabila diabaikan akan ada sanksi yang diberikan sesuai dengan ketentuan hukum yang berlaku.

Dengan berlakunya undang-undang Nomor 28 Tahun 2007 tentang Pajak dan Retribusi Daerah maka kewenangan pemungutan Pajak Bumi dan Bangunan sektor Pedesaan dan Perkotaan (PBB P2) telah diserahkan ke pemerintah kabupaten/kota. PBB sektor Pertambangan, Perhutanan, dan Perkebunan (PBB P3) masih berada di bawah kewenangan pemerintah pusat dalam hal ini Badan Pendapatan, Pengelolaan, Kekayaan Aset Daerah (BPPKAD) yang mengambil peranan tersebut.

Tata cara pelaksanaan pemunggutan Pajak Bumi dan Bangunan Pedesaan dan Perkotaan (PBB P2) diatur dalam Peraturan Bupati Kabupaten Magelang Nomor 16 Tahun 2012. Adapun manfaat pembayaran PBB P2 sebagai berikut: 1) tersedianya fasilitas dan infrastruktur desa; 2) ada subsidi pangan dan bahan bakar; 3) kelestarian hidup dan budaya; 4) dana pemilu, pilkada, pileg, dan pilkades; 5) pengembangan alat transportasi masa. Banyak yang menjadi faktor penyebab tidak lancarnya pembayaran PBB, salah satu fenomena ini terjadi di wilayah Kecamatan Bandongan, Kabupaten Magelang. Diantara berbagai macam faktor yang mendasari terjadinya penyebab kemacetan pembayaran PBB, penyebab kemacetan yang terjadi di Kecamatan Bandongan terdapat 2 (dua) faktor antara lain: 1) kesadaran diri; dan 2) kemiskinan.

Tulisan ini tentu saja melihat dari penelitian yang sebelumnya, jurnal ini berupaya membandingkan dengan jurnal yang telah terbit. Pertama, dengan judul Analisis Penerapan Pembasan PBB dan BPHTB terhadap Penerimaan Pajak Daerah UPPRD Tanjung Priok, jurnal ini membahas tentang kebijakan PBB dan BPHTB berdasarkan Peraturan Gubernur DKI Jakarta Nomor 259 Tahun 2015 dan Peraturan Gubernur DKI Jakarta Nomor 126 Tahun 2017, perbedaan terhadap penulisan peneliti adalah jurnal terbit tersebut membahas tentang analisis kebijakan berdasarkan Peraturan Gubernur yang berlaku (Aida Nurul Hidayah, dkk.2019). Kedua, Analisis pemungutan dan pencatatan PBB P2 pada Pemerintah Kabupaten Minahasa Tenggara, jurnal ini membahas tentang proses pemungutan dan pencatatan PBB P2 yang berlaku di Kabupaten Minahasa Tenggara, perbedaannya adalah jurnal ini ingin mencari tahu proses pemungutan dan pencatatan PBB P2(Lisa Tivani Langi, dkk.2018). Ketiga, Analisis Penerimaan PBB pada Dinas Pendapatan Daerah Kota Medan, jurnal ini membahas tentang bagaimana efektivitas penerimaan pembayaran PBB berdasarkan UU Nomor 32 Tahun 2004 tentang Pemerintahan Daerah, perbedaannya adalah jurnal ini membahas efektivitas penerimaan pembayaran PBB (Putri Kemala Dewi :2018).

Dari ketiga jurnal pembanding, penulis berupaya membahas tentang pokok permasalahan yang berbeda yaitu fenomena pembayaran PBB di Kecamatan Bandongan, Kabupaten Magelang, penulisan ini ingin mencaritahu tentang apa yang menjadi penyebab kemacetan pembayaran PBB di Kabupaten Magelang dengan menganalisis fenomena pembayaran PBB di Kecamatan Bandongan. Adapun penyebab kemacetan pembayaran PBB di Kecamatan Bandongan sebagai berikut: 1) kesadaran diri; dan 2) kemiskinan. Kesadaran diri adalah kemampuan individu dalam mengenali perasaan dan mengatur emosional. Orang yang mempunyai kesadaran diri diibaratkan pilot yang handal bagi kehidupannya, pasalnya mampu mengenal dan memilih-milih perasaan, memahami hal yang sedang dirasakan dan mengapa hal itu dirasakan serta mengetahui penyebab munculnya perasaan tersebut (Daniel Goleman, 1996:58). Dalam hal ini, terlihat adanya kesadaran diri masyarakat tingkat Kecamatan Bandongan sangat rendah, terbukti bahwa masih terdapat tunggakan. Padahal apabila ditelusuri lebih lanjut, masyarakat desa rata-rata mempunyai penghasilan tetap, selain menjadi petani. Kesadaran diri sebenarnya belum dapat menjawab pertanyaan yang ada tentang penyebab terjadinya kemacetan pembayaran PBB, bisa jadi WP mempunyai kesadaraan akan kewajibannya membayar PBB akan tetapi hanya saja faktor ekonomi yang mendasari tidak terbayarnya PBB pada tahun tersebut. 
Kemiskinan adalah suatu kondisi ketidakmampuan secara ekonomi untuk memenuhi standar hidup rata-rata masyarakat di suatu daerah. Kondisi ketidakmampuan ini ditandai dengan rendahnya kemampuan pendapatan untuk memenuhi kebutuhan pokok baik berupa pangan, sandang, maupun papan. Kemampuan pendapatan yang rendah ini juga akan berdampak berkurangnya kemampuan untuk memenuhi standar hidup rata-rata seperti standar kesehatan masyarakat dan standar pendidikan. Mengidentifikasi bentuk-bentuk kemiskinan yang ada di Kecamatan Bandongan terjadi karena kemiskinan alamiah, karena apabila petani di Kecamatan Bandongan mengalami gagal panen, secara otomatis tidak adanya pendapatan. Oleh karena itu, PBB tidak terbayarkan.

\section{METODE PENELITIAN}

Metode yang digunakan dalam penelitian ini adalah metode kualilatif deskriptif dengan pendekatan analisis kebijakan. Penulis ingin membahas tentang kebijakan pembayaran Pajak Bumi Dan Bangunan (PBB) di Kecamatan Bandongan Kabupaten Magelang menganalisis kebijakan ini dibuat untuk mengatasi kemacetan yang terjadi di Kecamatan Bandongan. Subyek penelitian dipilih berdasarkan teknik purposive sampling yaitu pelaksana pemungut pajak dan wajib pajak. Pengumpulan data dengan wawancara mendalam sedangkan teknik analisis data menggunakan metode analisis deskriptif. Lokasi penelitian berada di Kecamatan Bandongan.

\section{HASIL DAN PEMBAHASAN}

Pelaksanaan pembayaran PBB di Kecamatan Bandongan sudah melalui mekanisme atau prosedur yang telah ditetapkan, dinas yang bertanggung jawab penerbitan blangko SPPT sampai dengan adanya penerimaan PBB yang terbayarkan oleh WP adalah Badan Pendapatan, Pengelolaan, Kekayaan Aset Daerah (BPPKAD) Kabupaten Magelang. Keberhasilan perolehan pajak tidak serta merta dilakukan oleh BPPKAD semata, tanpa campur tangan pemerintahan kecamatan, desa, dan pemungungut pajak.

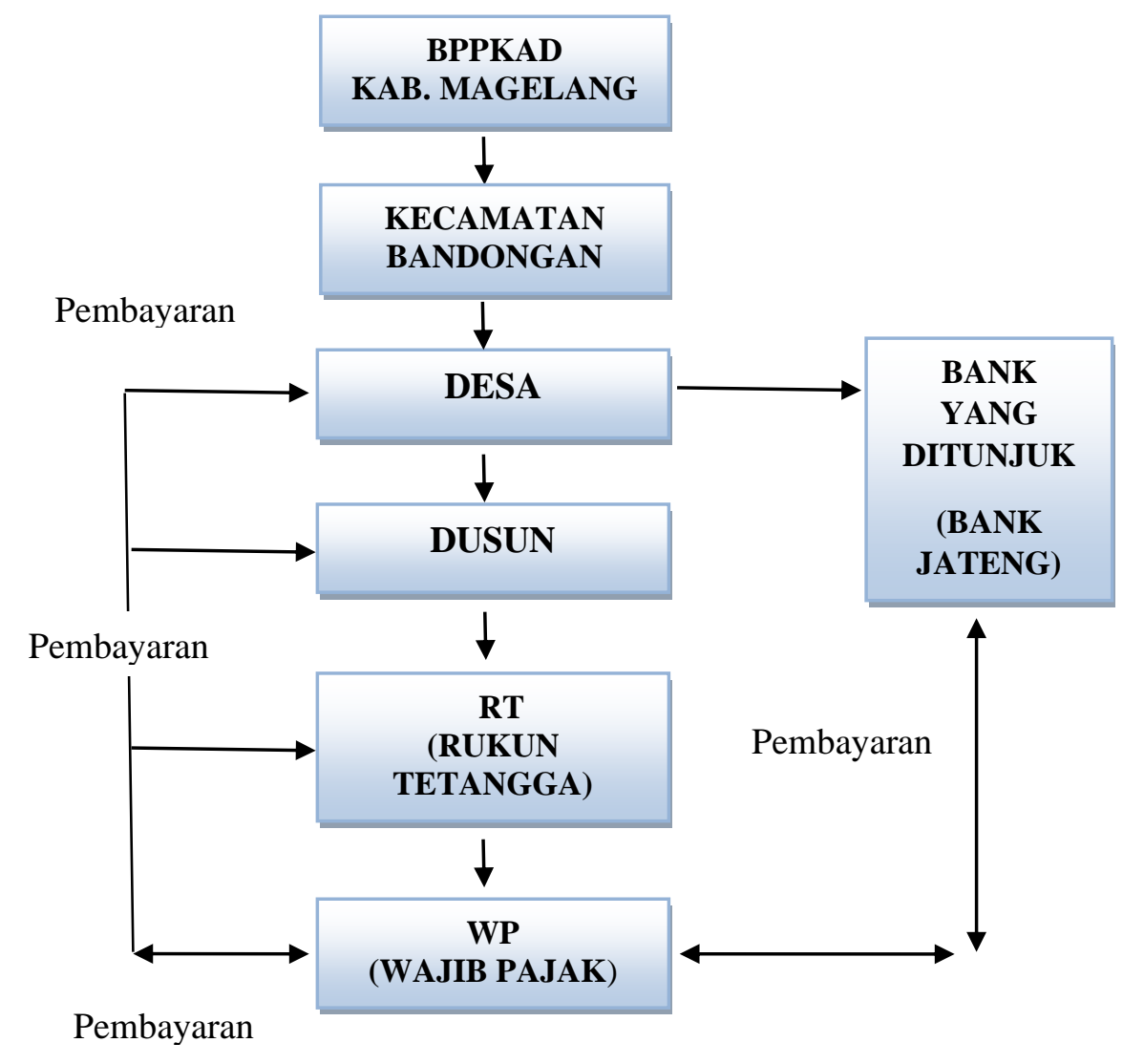

Gambar 1. Skema Pembayaran PBB di Kecamatan Bandongan Kabupaten Magelang 
Pemerintah Kecamatan, desa, maupun petugas pungut pajak merupakan sambung tangan dari BPPKAD, berhasil tidaknya suatu kecamatan dalam pelaksanaan pemungutan PBB terlihat dengan tidak adanya tunggakan PBB setiap tahunnya. Apabila masih didapati tunggakan dapat dilihat bagaimana kinerja desa dalam menyiasati adanya tunggakan yang terjadi di tahun sebelumnya, tujuannya adalah agar pada tahun ini, tidak terulang lagi dan dapat membayarkan jumlah tunggakan tertanggung. Banyak inovasi-inovasi yang diciptakan sebagai langkah awal mencegah terjadinya tunggakan. Berhasil atau tidak suatu inovasi tersebut, dapat dilihat melalui hasil rekapitulasi tahunan yang menjadi bahan analisa dan evaluasi BPPKAD.Setelah diketahui dari sekian kecamatan yang ada di Kabupaten Magelang, kecamatan yang banyak terdapat tunggakan adalah Kecamatan Bandongan.

Mekanisme yang di mulai dari penyerahan blangko SPPT hingga pembayaran PBB di Kecamatan Bandongan dapat dituangkan melalui skema gambar 1. Berdasarkan gambar 1 di atas bahwa BPPKAD Kabupaten Magelang mempunyai peranan penting, adapun tugas BPPKAD Kabupaten Magelang sebagai berikut: 1) menerbitkan blangko SPPT; 2) sosialisasi dan evaluasi kepada pemerintahan kecamatan terkait pelaksanaan PBB; dan 3) penerima pajak terbayar. Tugas Pemerintahan Kecamatan Bandongan adalah 1) mengambil blangko SPPT di kantor BPPKAD; 2) menghadiri sosialisasi dan evaluasi yang diadakan oleh BPPKAD; 3) sosialisasi dan evaluasi kepada pemerintahan desa terkait PBB; 4) pendistribusian blangko SPPT; dan 5) pengesahan pergantian blangko SPPT.

Tugas Pemerintah Desa adalah 1) mengambil blangko SPPT di kantor kecamatan; 2) menghadiri sosialisasi dan evaluasi yang diadakan oleh kecamatan; 3) sosialisasi dan evaluasi kepada kepala dusun dan pemungut pajak dusun; 4) membuatkan surat terbit perubahan PBB; dan 5) sarana pembayaran kolektif PBB. Adapun cara pembayaran PBB di Kecamatan Bandongan berdasarkan skema di atas, yaitu : 1) WP membayar langsung ke Bank yang telah ditunjuk (Bank Jateng); 2) WP dapat membayar melalui perantara dari desa; 3) WP dapat membayar melalui kepala dusun; dan atau 4) WP membayar melalui ketua Rukun Tetangga (RT). Faktor yang menjadi penyebab terjadinya kemacetan PBB di Kecamatan Bandongan adalah 1) kesadaran diri; dan 2) kemiskinan. Dalam hal ini, terlihat adanya kesadaran diri masyarakat tingkat Kecamatan Bandongan sangat rendah, terbukti bahwa masih terdapat tunggakan.

Tabel 1. Realisasi Penerimaan BB Kabupaten Magelang Tahun 2020

\begin{tabular}{clcccc}
\hline \multirow{2}{*}{ NO } & \multirow{2}{*}{ KECAMATAN } & \multicolumn{4}{c}{ REALISASI PBB (NOMINAL DAN \%) } \\
\cline { 3 - 6 } & & POKOK PBB & REALISASI & KURANG & \% \\
\hline 1 & NGABLAK & 1.025 .598 .895 & 1.025 .598 .895 & 0 & 100 \\
\hline 2 & SRUMBUNG & 1.344 .681 .680 & 1.344 .681 .680 & 0 & 100 \\
\hline 3 & CANDI MULYO & 1.471 .712 .401 & 1.471 .712 .401 & 0 & 100 \\
\hline 4 & KALIANGKRIK & 1.104 .182 .018 & 1.048 .152 .394 & 56.029 .624 & 94.93 \\
\hline 5 & SAWANGAN & 1.496 .368 .683 & 1.427 .314 .087 & 69.054 .596 & 95,39 \\
\hline 6 & NGLUWAR & 965.884 .718 & 863.712 .997 & 102.171 .721 & 89.42 \\
\hline 7 & DUKUN & 1.401 .039 .105 & 1.297 .009 .009 & 104.030 .096 & 92.57 \\
\hline 8 & WINDUSARI & 1.120 .504 .430 & 977.903 .777 & 142.600 .653 & 87.27 \\
\hline 9 & SALAMAN & 1.748 .387 .856 & 1.442 .214 .815 & 306.173 .041 & 82.49 \\
\hline 10 & SALAM & 1.748 .387 .856 & 1.445 .760 .464 & 342.179 .415 & 80.86 \\
\hline 11 & KAJORAN & 1.632 .515 .365 & 1.213 .701 .314 & 418.814 .051 & 74.35 \\
\hline 12 & BANDONGAN & 1.581 .425 .622 & 1.160 .056 .853 & 421.368 .769 & 73.36 \\
\hline 13 & GRABAG & 2.243 .974 .164 & 1.811 .104 .429 & 432.869 .735 & 80.71 \\
\hline 14 & TEMPURAN & 2.143 .042 .702 & 1.659 .729 .984 & 483.312 .718 & 77.45 \\
\hline 15 & PAKIS & 1.383 .221 .875 & 867.453 .079 & 515.768 .796 & 62.71 \\
\hline 16 & TEGALREJO & 1.342 .301 .790 & 796.174 .100 & 546.127 .690 & 59.31 \\
\hline 17 & MUNGKID & 2.121 .941 .891 & 1.558 .384 .099 & 563.557 .792 & 73.44 \\
\hline 18 & BOROBUDUR & 1.977 .160 .418 & 1.404 .719 .187 & 572.441 .231 & 71.05 \\
\hline 19 & MUNTILAN & 2.352 .318 .311 & 1.767 .837 .915 & 584.480 .396 & 75.15 \\
\hline 20 & METROYUDAN & 3.222 .033 .189 & 2.179 .455 .300 & 1.042 .577 .889 & 67.64 \\
\hline 21 & SECANG & 2.448 .317 .561 & 1.239 .991 .750 & 1.208 .325 .811 & 50.65 \\
\hline & JUMLAH & 35.914 .552 .553 & 28.002 .668 .529 & 7.911 .884 .024 & 77.97 \\
\hline & & Sumber: Data Bank Jateng Desember 2020. & &
\end{tabular}


Padahal apabila ditelusuri lebih lanjut, masyarakat desa rata-rata mempunyai penghasilan tetap, selain menjadi petani. Kesadaran diri sebenarnya belum dapat menjawab pertanyaan yang ada tentang penyebab terjadinya kemacetan pembayaran PBB, bisa jadi WP mempunyai kesadaraan akan kewajibannya membayar PBB akan tetapi hanya saja faktor ekonomi yang mendasari tidak terbayarnya PBB pada tahun tersebut. Bukan saja rendahnya kesadaraan diri masyarakat Kecamatan Bandongan, akan tetapi faktor ekonomi yaitu kemiskinan juga menjadi satu alasan penyebab tidak terbayarkannya PBB.

Kemiskinan juga menjadi salah satu penyebab terjadinya kemacetan di Kecamatan Bandongan, apabila dilihat dari sudut pandang pengukuran masyarakat Kecamatan Bandongan termasuk kedalam kemiskinan relatif, karena yang menjadi tolak ukur hanya sekitar daerah tempat tinggal, dan boleh dikatakan karena pekerjaan harian hanya bercocok tanam yang mendapat penghasilan ketika menjual hasil panen tersebut, sedangkan penyebab kemiskinan termasuk kemiskinan alamiah, karena apabila petani di Kecamatan Bandongan mengalami gagal panen, secara otomatis tidak adanya pendapatan.Oleh karena itu, PBB tidak terbayarkan. Adapun data rekapitulasi kecamatan-kecamatan wilayah Kabupaten Magelang yang tidak lunas dalam pembayaran PBB pada tabel 1.

Dari keterangan Tabel 1 dapat dilihat bahwa 3 dari 21 kecamatan yang tidak terdapat tunggakan atau dapat terbayar 100 persen yaitu Kecamatan Ngablak, Srumbung, dan Candimulyo, sedangkan Kecamatan Bandongan termasuk masih terdapat tunggakan. Hal ini menjadi fenomena akan banyaknya tunggakkan yang terjadi di Kabupaten Magelang, adapun latarbelakang yang mempengaruhi terjadinya kemacetan dalam pelaksanaan pembayaran PBB yaitu rendahnya kesadaran dan kemiskinan.

\section{KESIMPULAN}

Terjadinya kemacetan pembayaran PBB di Kecamatan Bandongan, Kabupaten Magelang dikarenakan rendahnya kesadaran diri masyarakatnya, menunda pembayaran dan terjadi penumpukan tunggakan serta kemiskinan yang disebabkan gagal panen, sehingga tidak dapat melakukan pembayaran PBB pada tahun tersebut, sedangkan mekanisme pembayaran sudah dipermudah dengan cara, sebagai berikut : 1) WP membayar langsung ke Bank yang telah ditunjuk (Bank Jateng); 2) WP dapat membayar melalui perantara dari desa; 3) WP dapat membayar melalui kepala dusun; dan atau 4) WP membayar melalui ketua Rukun Tetangga (RT).

\section{REFERENSI}

Aida, N,H, dkk.,2019, Analisis Penerapan Pembebasan PBB dan BPHTB Terhadap Penerimaan Pajak Daerah, Universitas Negeri Jakarta, Jakarta.

Cresswell,2008,Research Design,Pustaka Belajar, Yogyakarta.

Daniel, G., 1996, Emotional Intelligence: Mengapa El Lebih Penting Daripada EQ, hal58.terj.Hermaya, Gramedia, Jakarta.

Dunn, W.,2000, Pengantar Analisis Kebijakan, hal21, Gajah Mada University Press, Yogyakarta.

Erly, S.,2005,Hukum Pajak,Edisi Kedua, Salemba Empat, Jakarta.

Kartasasmita, G.,1996, Pembangunan untuk Rakyat Memadukan Pertumbuhan dan Pemerataan, hal 234-235, PT. Pustaka Cidesindo, Jakarta.

Koeworo,1987,Psikologi Eksistensial,hal 31,Eresco, Bandung.

Lisa, T, L,dkk.,2018,Analisis Pemungutan dan Pencatatan PBB P2 pada Pemerintah Kabupaten Minahasa Tenggara, Universitas Sam Ratulangi, Manado.

Marihot, P, S., 2004, Pajak Daerah dan Retribusi Daerah (hlm 154).,Edisi Revisi, Rajawali Pers, Jakarta.

Porwandari, E,K.,2005,Pendekatan Kualitatif untuk Penelitian Perilaku Manusia (edisi: Ketiga), LPSP3 Fakultas Psikologi Universitas Indonesia, Depok. 
Putri, K, D.,2018, Analisis Penerimaan PBB pada Dinas Pendapatan Daerah Kota Medan, Universitas Brawijaya, Malang.

Sastrowardoyo, 1991,Teori Kepribadian Rollo May (hlm 83-84), Balai Pustaka, Jakarta.

Save, M, D., 1990, Filsafat Eksistensial (hlm 51), Rineka Cipta, Jakarta.

Semiawan, C, R.,2010,Metode Penelitian Kualitatif, Grasindo, Jakarta.

Siti,Z.,2020,Pengumuman Telat Bayar PBB Pemkab Magelang Berlaku Denda, Borobudurnews, Magelang.

Sugiyono, 2012, Metode Penelitian Kuantitatif, Kualitatif dan R\&D, Alfabeta, Bandung.

Suryo, S,A.,2006, Perpajakan Indonesia, hal14.vol.2, Salemba Empat, Jakarta.

Steven, J, S, and Book, Howard E.,2000, Ledakan EQ: 15 Prinsip Dasar Kecerdasan Emosional Meraih Sukses, hal 75, Kaifa, Bandung.

Syarifudin,2010,Jurnalitik Terapan (hlm 358), Ghalia Indonesia, Bogor.

Widjaja, 2004 ,Otonomi Desa, Rajawali Pers, Jakarta.

Undang-Undang Nomor 12 Tahun 1994 tentang Pajak Bumi dan Bangunan.

Undang-Undang Nomor 28 Tahun 2007 tentang Pajak dan Retribusi Daerah.

Undang-Undang Nomor 28 Tahun 2009 tentang Pajak Daerah

Peraturan Bupati Kabupaten Magelang Nomor 16 Tahun 2012 tentang Tata Cara Pelaksanaan Pemunggutan Pajak Bumi dan Bangunan Pedesaan dan Perkotaan (PBB P2) . 